\title{
PENGARUH KAPASITAS PENGERINGAN TERHADAP KARAKTERISTIK GABAH MENGGUNAKAN SWIRLING FLUIDIZED BED DRYER(SFBD)
}

\section{THE EFFECT OF DRYING CAPACITY ON ROUGH RICE CHARACTERISTICS USING SWIRLING FLUIDIZED BED DRYER (SFBD)}

\author{
Novrinaldi, Satya Andika Putra \\ Pusat Penelitian Teknologi Tepat Guna (P2 TTG), \\ Lembaga Ilmu Pengetahuan Indonesia (LIPI) \\ Jl. K.S. Tubun No.5 Subang, Jawa Barat 41213 \\ e-mail: naldi.novri@gmail.com, satya.andika.p@gmail.com
}

Diterima : 19-03-2019

Direvisi : 29-04-2019

Disetujui : 25-06-2019

\begin{abstract}
ABSTRAK
Penelitian ini bertujuan untuk melihat karakteristik gabah hasil pengeringan dengan melakukan percobaan menggunakan swirling fluidized bed dryer (SFBD) dengan variasi beban pengeringan. Gabah dengan berat $200 \mathrm{gr}, 250 \mathrm{gr}$ dan $300 \mathrm{gr}$ masing-masing dikeringkan selama 60 menit dengan pengambilan sampel sebanyak 9 kali seberat $10 \mathrm{gr}$. Pengambilan sampel dilakukan pada menit ke-0, 5, 10, 17, 24, $32,40,48$ dan menit ke- 60 . Setiap pengambilan sampel dicatat data temperatur dan kelembaban relatif (Rh) pada plenum dan ruang pengering. Penurunan kadar air gabah relatif seragam dan terjadi penurunan kadar air yang signifikan pada 5 menit pertama pengeringan dimana kadar air bebas pada permukaan gabah masih banyak. Selama proses pengeringan kadar air gabah turun dari $29.25 \%$ menjadi $14.03 \%$, $28.58 \%$ menjadi $14.21 \%$ dan $26.8 \%$ menjadi $13.78 \%$. Rh ruang pengering menurun akibat kenaikan temperatur pengeringan. Massa air yang diuapkan dari gabah sebesar $31.17 \mathrm{gr}, 38.26 \mathrm{gr}$ dan 41.82gr untuk masing-masing kapasitas. Humidity ratio antara plenum dengan ruang pengering berbanding terbalik, dimana pada ruang pengering humidity ratio akan naik dan pada plenum humidity ratio akan turun hal ini disebabkan oleh naiknya temperatur dan dengan dihembuskannya udara panas. Selisih humidity ratio antara ruang pengering dengan plenum pada menit akhir pengeringan berkisar antara $5-7 \mathrm{~g} / \mathrm{kg}$.
\end{abstract}

Kata Kunci : Pengeringan, kadar air, SFBD, temperatur, Rh

\begin{abstract}
This research aims to look at the characteristics of grain produced by drying by conducting experiments using swirling fluidized bed dryer (SFBD) with variations in drying load. Rough rice with a weight of $200 \mathrm{gr}, 250 \mathrm{gr}$ and, $300 \mathrm{gr}$ each dried for 60 minutes with sampling nine times as weight as $10 \mathrm{gr}$. Sampling was carried out at 0, 5, 10, 17, 24, 32, 40, 48 and 60 minutes. Each sample recorded temperature and relative humidity (Rh) data in the plenum and drying chamber. The decrease in rough rice moisture content was relatively uniform, and there was a significant decrease in moisture content in the first 5 minutes of drying where there was still a lot of free moisture content on the rough rice surface. During the drying process, the rough rice water content dropped from $29.25 \%$ to $14.03 \%, 28.58 \%$ to $14.21 \%$ and $26.8 \%$ to $13.78 \%$. The relative humidity of the drying chamber decreases due to the increase in drying temperature. The evaporated water mass of the rough rice are $31.17 \mathrm{gr}, 38.26 \mathrm{gr}$ and $41.82 \mathrm{gr}$ for each capacity. Humidity ratio between the plenum and the drying chamber is inversely proportional, wherein the drying chamber the humidity ratio will increase, and the plenum humidity ratio will decrease this is due to the increase in temperature and the exhaling of hot air. The humidity ratio difference between the drying chamber and the plenum in the final minutes of drying ranged from $5-7 \mathrm{~g} / \mathrm{kg}$.
\end{abstract}

Keywords: Drying, moisture content, SFBD, temperature, $R h$ 


\section{PENDAHULUAN}

D adi dengan nama latin Oryza Satifa $L$ merupakan hasil pertanian dari jenis biji-bijian yang dapat ditemukan hampir di seluruh Indonesia. Salah satu penanganan pascapanen yang dilakukan petani untuk menjaga kualitas padi atau gabah selama proses penyimpanan adalah dengan pengeringan yakni menurunkan kadar air gabah dari 20$23 \%$ basis kering pada musim kering atau $24-27 \%$ basis basah pada musim hujan menjadi $14 \%$ sesuai dengan syarat mutu SNI 01-0224-1987. Syarief dan Halid (1993) menyatakan bahwa kadar air biji-bijian yang aman untuk disimpan umumnya sekitar 13.5-14\%, sedangkan kadar air yang aman dari gangguan kerusakan adalah 11-12\%. Penurunan kadar air biji-bijian tersebut dapat dilakukan dengan cara proses pengeringan.

Pengeringan adalah proses pengurangan kadar air suatu bahan sampai pada batas tertentu dengan menggunakan energi panas yang bertujuan untuk menjaga kualitas bahan. Dasar proses pengeringan adalah terjadinya penguapan air ke udara karena adanya perbedaan kandungan uap air antara udara dengan bahan yang dikeringkan, kadar air dalam udara lebih sedikit sehingga uap air dari bahan bisa ditampung dalam udara. Pada proses pengeringan berlangsung terjadi dua proses secara bersamaan yakni perpindahan panas dari lingkungan ke bahan dan perpindahan massa dari bahan ke lingkungan. Proses perpindahan panas dipengaruhi oleh perubahan temperatur pengering dan proses perpindahan massa air dipengruhi oleh transfer panas dan transfer momentum. Perpindahan massa air ditandai dengan pengurangan massa bahan dan perubahan bentuk fisik (tekstur, warna dan fasa) (Dwika et al.,2012). Laju pengeringan pada bahan terjadi dalam dua periode yakni laju pengeringan konstan dimana terjadi pada bahan yang mengandung banyak air atau air permukaan yang mudah diuapkan, laju pengeringan konstan berhenti ketika air bebas dipermukaan habis menguap. Laju pengeringan menurun terjadi setelah laju pengeringan konstan dimana kadar air bahan lebih kecil dari pada kadar air kritis. Laju pengeringan ini menurun seiring dengan penurunan kadar air selama pengeringan. Jumlah air terikat makin lama semakin berkurang. Pada periode laju pengeringan menurun permukaan partikel bahan yang dikeringkan tidak lagi ditutupi oleh lapisan air.

Pengeringan dianggap penting karena akan menentukan kualitas gabah dan kualitas gabah akan mempengaruhi kualitas dan kuantitas beras yang nantinya akan dikonsumsi (Napitu, 2016). Secara umum pengeringan dapat dilakukan secara manual atau konvensional dan secara mekanis dengan menggunakan alat pengering. Pengeringan konvensional dengan panas matahari langsung merupakan cara yang paling mudah dan murah karena tidak membutuhkan biaya yang besar namun membutuhkan lahan yang luas, mudah terkontaminasi benda asing, terkendala musim hujan dan membutuhkan waktu yang lebih lama yakni 3-4 hari. Sedangkan dengan menggunakan alat pengering kapanpun proses pengeringan bisa dilakukan dengan kapasitas pengeringan yang bisa disesuikan dengan kebutuhan. Pengeringan secara mekanis membutuhkan biaya yang lebih besar karena membutuhkan sumber energi namun secara keseluruhan akan lebih menguntungkan karena menurut Hosokawa (1995) dalam Napitu (2016) resiko kehilangan pengeringan secara mekanis lebih kecil yakni $2.3 \%$ dibandingkan dengan pengeringan konvensional yakni $2.98 \%$.

Faktor yang mempengaruhi proses pengeringan terdiri dari yakni faktor yang berhubungan dengan udara pengering yakni dan faktor yang berhubungan dengan sifat bahan yang akan dikeringkan. Faktor dari kelompok pertama terdiri dari temperatur, kecepatan volumetrik aliran udara pengering dan kelembaban udara. Sedangkan faktor yang mempengaruhi pengeringan dari sifat bahan terdiri dari ukuran bahan (luas permukaan bahan), kadar air awal dan tekanan parsial di dalam bahan (Taib et al., 1988). Menurut Lee dan Chung (1985) temperatur udara pengering merupakan efek yang paling besar yang mempengaruhi laju pengeringan pada lapisan tipis dan laju aliran udara dan kelembaban relatif memiliki efek yang lebih kecil. Kedua kelompok ini akan mempengaruhi laju pengeringan yang 
merupakan parameter penting yang perlu dikendalikan selama proses pengeringan (Dina et al., 2018). Laju pengeringan yang terlalu lambat akan menyebabkan berkembangnya jamur pada gabah.

Fluidisasi merupakan suatu operasi dimana partikel padat diubah menjadi seperti keadaan cairan melalui suspensi dalam gas atau cairan. Fluidisasi terjadi bila terjadi interaksi antara hamparan padatan dan aliran fluida yang mengubah partikel padat menjadi berperilaku seperti fluida (Kunii dan Levenspiel, 1991). Pengering fluidisasi mempunyai beberapa kelebihan yaitu laju perpindahan panas dan masa cukup tinggi karena kontak antara udara panas pengering dengan bahan yang dikeringkan cukup baik, temperatur dan kadar air seragam, kontruksi sederhana, kapasitas pengeringan tinggi (Yahya, 2015). Pengeringan menggunakan SFBD memiliki laju pengeringan yang lebih efektif karena gerakan fluidisasi dan berputarnya bahan mengelilingi conus centre body atau aliran swirl menyebabkan semua permukaan bahan akan terkena udara panas sehingga diharapkan proses perpindahan panas dari udara pengering ke bahan dan perpindahan massa dari bahan ke udara terjadi secara maksimal. Pada penelitian ini dilakukan pengujian alat pengering sistem fluidisasi swirling fluidized bed dryer (SFBD) untuk mengeringkan gabah. Penelitian ini bertujuan untuk mengetahui performansi atau kinerja pengering SFBD terhadap pengeringan gabah dengan melihat karakteristik gabah setelah proses pengeringan. Oktianto dan Prabowo (2014) telah melakukan penelitian pengeringan menggunakan SFBD dengan bahan batu bara, pada penelitian tersebut dilakukan variasi sudut pengarah dimana sudut pengarah dari annular blade distrbutor sebesar $10^{\circ}$ menghasilkan penurunan kadar air batu bara terbaik yakni dari $27.3 \%$ menjadi $6.8 \%$. Batcha et all., 2012) juga telah melakukan penelitian pengeringan menggunakan SFBD untuk mengeringkan daun kelapa sawit, ditemukan bahwa SFBD mampu memberikan karakteristik pengeringan fluidisasi yang baik dengan pencampuran yang baik antar partikel.

\section{METODE PENELITIAN}

Metode yang digunakan dalam penelitian ini termasuk kategori eksperimental pengujian alat pengering tipe swirling fluidized bed. Alat pengering SFBD diuji dengan menggunakan bahan gabah padi jenis ciherang dengan variasi kapasitas $200 \mathrm{gr}, 250 \mathrm{gr}$ dan $300 \mathrm{gr}$. Selama proses pengeringan diukur dan dicatat temperatur, kelembaban relatif dan tekanan pada plenum dan ruang pengering serta kadar air gabah pada setiap pengambilan sampel. Penelitian ini dilakukan selama satu tahun yakni dari bulan Februari 2017 hingga Februari tahun 2018. Tempat pelaksanaan penelitian adalah di Pusat Penelitian Teknologi Tepat Guna (P2 TTG), Lembaga Ilmu Pengetahahuan Indonesia (LIPI).

\section{Bahan dan alat}

Bahan uji coba yang digunakan dalam penelitian ini berupa gabah jenis ciherang. Gabah yang digunakan merupakan gabah kering dengan kadar air $12.44 \%$ yang diperoleh dari daerah Subang, Jawa Barat, hal ini dikarenakan ketersedian gabah hasil panen atau gabah kering panen (GKP) dengan kadar air $18-25 \%$ sulit diperoleh pada saat uji coba dilakukan. Untuk menaikkan kadar air gabah dilakukan proses rehidrasi selama 24 jam (Ferdiansyah, 2003) dengan cara merendam gabah yang kemudian diitriskan dan diukur kadar airnya. Alat yang digunakan dalam penelitian ini berupa alat utama dan alat pendukung pengujian. Alat ukur utama berupa mistar, digital anemometer, u-tube manometer dilengkapi dengan kertas millimeter block, tang ampere, Rh meter, data logger "omega" dan thermocouple type $k$, thermocontroler, infrared thermometer, oven "Memert", timbangan digital, gelas ukur, blender. Alat pendukung terdiri dari kotak plastik untuk perendaman gabah, peniris, panci, penampi dan tisu, kantong plastik, kotak plastik untuk sampel, dan timbangan digital. 


\section{Pengujian dan Pengumpulan Data}

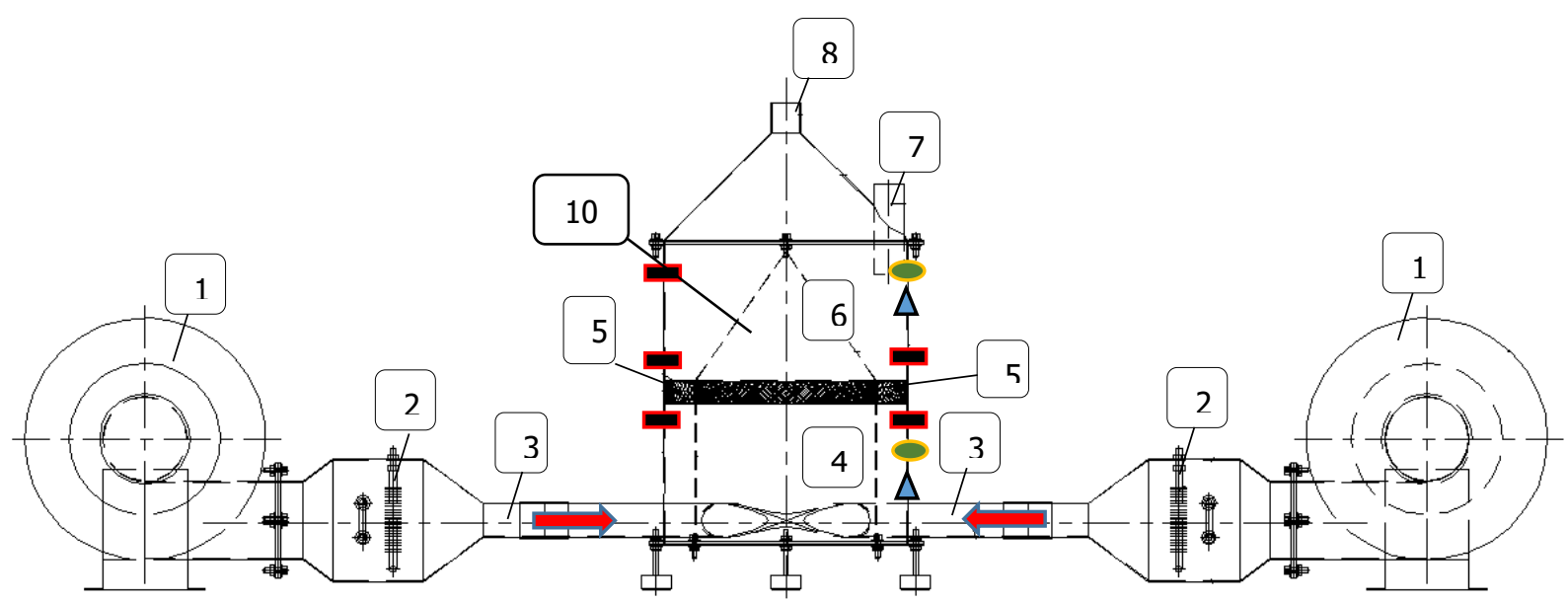

Gambar 1. Skema mekanisme kerja dan pengukuran temperatur, kelembaban relatif dan tekanan alat pengering sistem fluidisasi berputar

Keterangan :

1 : Peniup udara (Blower)

2 : Pemanas (heater)

3 : Pipa saluran udara panas

$4:$ Plenum

5 : Pengarah aliran udara (Annular blade distributor)

6 : Ruang pengering

7 : Pengumpan (feeder)

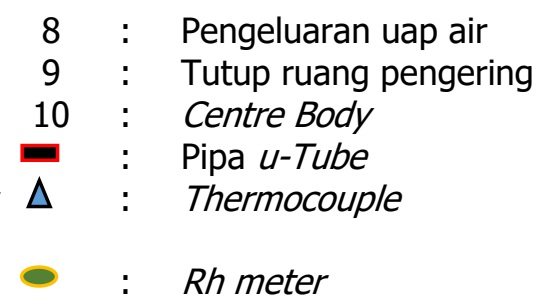

Alat pengering SFBD skala laboratorium yang digunakan dalam penelitian ini memiliki tinggi $500 \mathrm{~mm}$, diameter plenum dan diameter ruang pengering $400 \mathrm{~mm}$ dan diameter centre body $300 \mathrm{~mm}$. Pengarah aliran udara yang tersusun dari bilah dengan ukuran panjang $50 \mathrm{~mm}$ dan lebar $40 \mathrm{~mm}$ sebanyak 100 bilah. Energi panas bersumber dari heater dengan total daya $5 \mathrm{~kW}$ dan udara untuk fluidisasi yang digunakan bersumber dari dua unit blower. Pengujian proses pengeringan gabah diawali dengan menghamparkan gabah di atas annular blade ditributor yang dilengkapi dengan ram kawat, kemudian tutup ruang pengering dipasangkan kembali dan pemanas ( heater) dinyalakan dengan setingan temperatur $45^{\circ} \mathrm{C}$ selama \pm 3 menit hingga temperatur pada ruang pemanas naik. Blower dinyalakan sehingga udara yang ditiup oleh blower melewati pemanas yang menyebabkan temperatur udara yang akan masuk ke ruang pengering melewati pipa saluran udara menjadi naik. Udara panas dari plenum ke ruang pengering di arahkan oleh annular blade distributor dengan sudut kemiringan blade $45^{\circ}$ sehingga menyebabkan gabah terangkat dan terbang mengelilingi ruang pengering. Setelah proses pengeringan selesai pada menit ke-60 blowerdimatikan dan bahan diangkat dari ruang pengering.

Metode pengambilan data menggunakan pengambilan data primer yaitu melakukan pengamatan langsung unjuk kerja pengering (Rahayuningtyas dan Kuala, 2015). Proses pengambilan data menggunakan beberapa alat ukur yang terdiri dari data logger dan Thermocouple type $k$ untuk pengukuran temperatur pada ruang plenum atau di bawah distributor dan ruang pengering atau di atas distributor, Rh meter untuk mengukur 
kelembaban relatif udara pada ruang plenum (di bawah distributor), ruang pengering (di atas distributor) dan lingkungan, serta pipa u-tube untuk mengukur tekanan pada posisi sebelum dan sesudah annular blade distributor serta bagian atas ruang pengering. Waktu pengujian ditetapkan sama yakni selama 60 menit. Pengambilan sampel dilakukan sebanyak 9 kali tanpa menghentikan proses pengeringan yakni pada menit ke-0, 5, 10, 17, 24, 32, 40, 48 dan pada menit akhir pengeringan yaitu menit ke-60 dengan berat masing-masing sampel sebesar 10 gr. Sampel pada menit ke-0 untuk mengukur kadar air awal gabah sebelum dikeringkan diambil tanpa mengurangi dari kapasitas pengujian pengeringan. Sedangkan perlakuan pengambilan sampel untuk menit selanjutnya diambil dengan mengurangi massa gabah yang dikeringkan.

\section{Analisis data pengujian}

Analisis data peneltian ini untuk melihat karakteristik gabah hasil pengeringan. Data yang dianalisis berupa udara pengering dan bahan yang dikeringkan. Analisis dari sisi udara pengering dengan menggunakan psychrometric chart seperti disajikan gambar 2 . Psychrometric chart merupakan gambaran dari sifat-sifat termodinamika dari udara basah dan variasi proses sistem penyegaran udara dan siklus sistem penyegaran udara (Permana, 2016). Pada analisis ini akan diketahui massa uap air yang ada dalam udara kering sebagai akibat dari berpindahnya massa air dari gabah ke udara sekitarnya selama proses pengeringan. Analisis dilakukan dengan cara memplotkan data temperetur dry bulb plenum dengan kelembaban relatif (Rh) plenum, dan temperatur dry bulb ruang pengering dengan kelembaban relatif $(\mathrm{Rh})$ ruang pengering yang didapat selama proses pengeringan. Analisis terhadap gabah atau bahan yang dikeringkan dilakukan dengan mengukur kadar air gabah pada setiap pengambilan sampel. Pengukuran kadar air dilakukan dengan metode ASTM D5142 pada temperatur $105^{\circ} \mathrm{C}$ selama 3 jam.

\section{HASIL DAN PEMBAHASAN}

Pada penelitian ini dilakukan pengujian alat pengering SFBD untuk pengeringan gabah dengan variasi kapasitas pengeringan. Hasil yang diperoleh dari pengujian berupa data udara pengering dan gabah yang dikeringkan. Data pengujian udara pengering berupa temperatur udara $(T)$ ruang pengering (drying chamber), kelembaban relatif ( $R h$ ) ruang pengering, dan ratio kelembaban $(\Delta \mathrm{w})$ menggunakan psychrometric chart. Dari gabah yang dikeringkan diperoleh data kadar air (moisture content/ mc).

Gambar 2 menunjukkan proses pengeringan gabah dalam psychrometric chart mulai dari menit awal pengeringan, dimana pada kondisi ini udara pengering belum dihembuskan ke ruang pengering dan bahan sudah dihamparkan dalam ruang pengering. Temperatur ruang pengering merupakan temperatur lingkungan dan kelembaban relatif pada ruang pengering masih tinggi. Pada saat blower dinyalakan udara mengalir melewati heater yang sudah dinyalakan sebelumnya selama \pm 5 menit, temperatur udara ruang pengering meningkat dan kelembaban relatif udara turun. Kadar air dalam udara pada menit awal pengeringan masih sedikit. Pada menit akhir pengeringan kadar air dalam udara ruang pengering meningkat hal ini menunjukkan terjadinya perpindahan massa air dari gabah ke udara sebagai akibat dari perpindahan panas dari udara panas ke gabah. Perpindahan massa air ke udara terhenti ketika tercapai keseimbangan kadar air dalam bahan dengan kadar air dalam udara. 


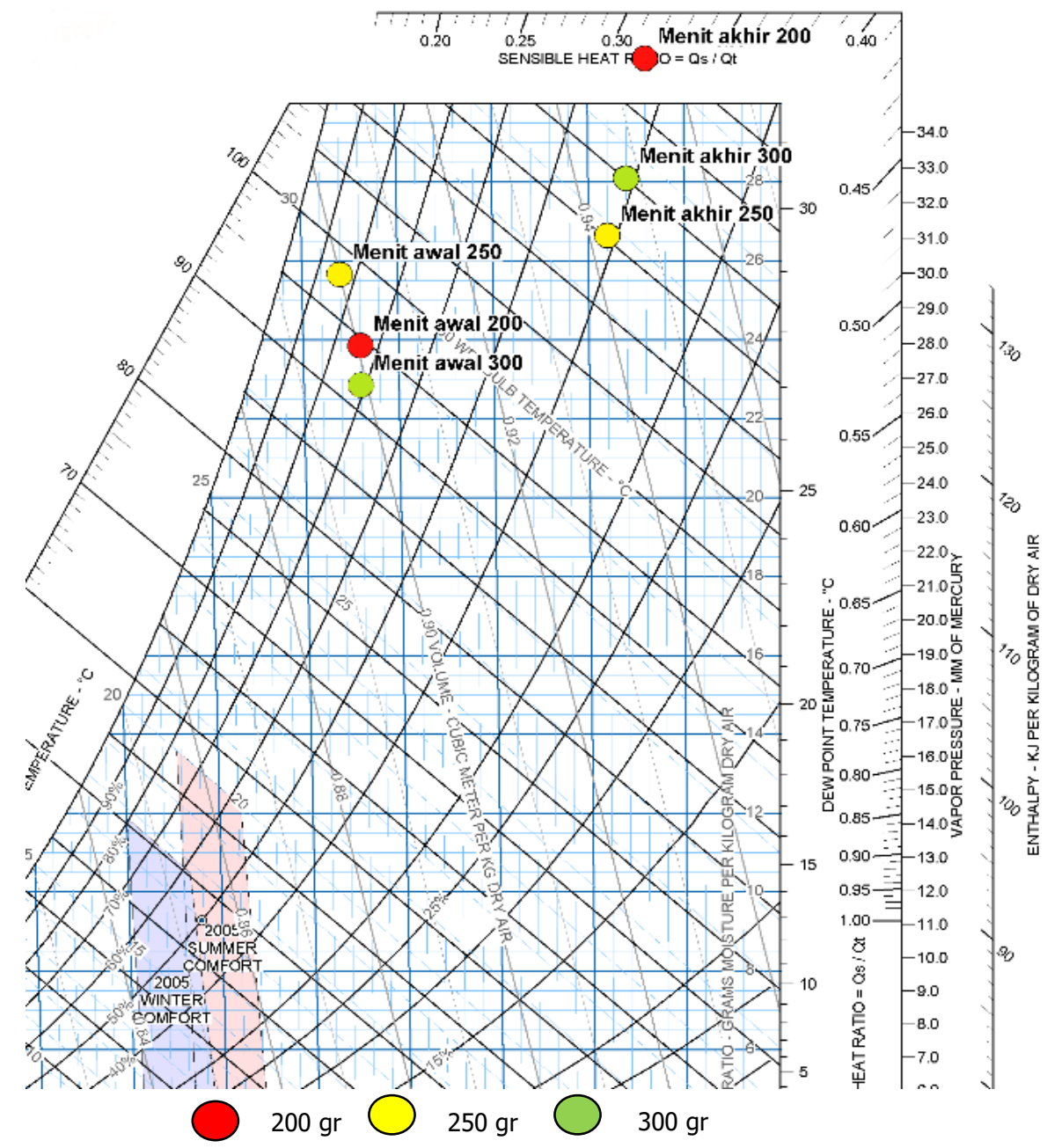

Gambar 2. Proses pengeringan gabah dalam psychrometric chart

Persentase kadar air awal gabah pada setiap kapasitas proses pengeringan berbedabeda. Dari gambar 3 menunjukkan kapasitas pengeringan paling sedikit yakni $200 \mathrm{gr}$ memiliki persentase kadar air yang paling besar yakni $29.25 \%$, diikuti dengan kapasitas $250 \mathrm{gr}$ dan 300 gr dengan kadar air masing-masing $28.58 \%$ dan $26.8 \%$, hal ini disebabkan karena sampel uji coba diambil dari gabah hasil perendeman (rehidrasi) yang berbeda namun dari jenis gabah yang sama yakni gabah jenis ciherang. Gambar 3 juga menunjukkan tren penurunan persentase kadar air gabah yang relatif seragam dari menit awal (menit ke-0) hingga menit akhir (menit ke-60) pada setiap kapasitas pengeringan. Penurunan persentase kadar air akhir gabah dipengaruhi oleh kadar air awal pada masing-masing kapasitas. Dengan persentase kadar air akhir (pada menit ke-60) yang hampir seragam yakni 14.03\%, 14.21 dan $13.78 \%$ untuk masing-masing kapasitas pengeringan, gabah yang memiliki kadar air awal terbesar memiliki persentase penurunan kadar air yang paling tinggi yakni sebesar $15.22 \%, 14.37 \%$ dan $13.02 \%$. Dari ke tiga variasi percobaan, pengeringan dengan kapasitas yakni $300 \mathrm{gr}$ mencapai kadar air akhir yang sudah memenuhi kadar air maksimal gabah sebesar $14 \%$ menurut Standar Nasional Indonesia (SNI 01-0224-1987). 


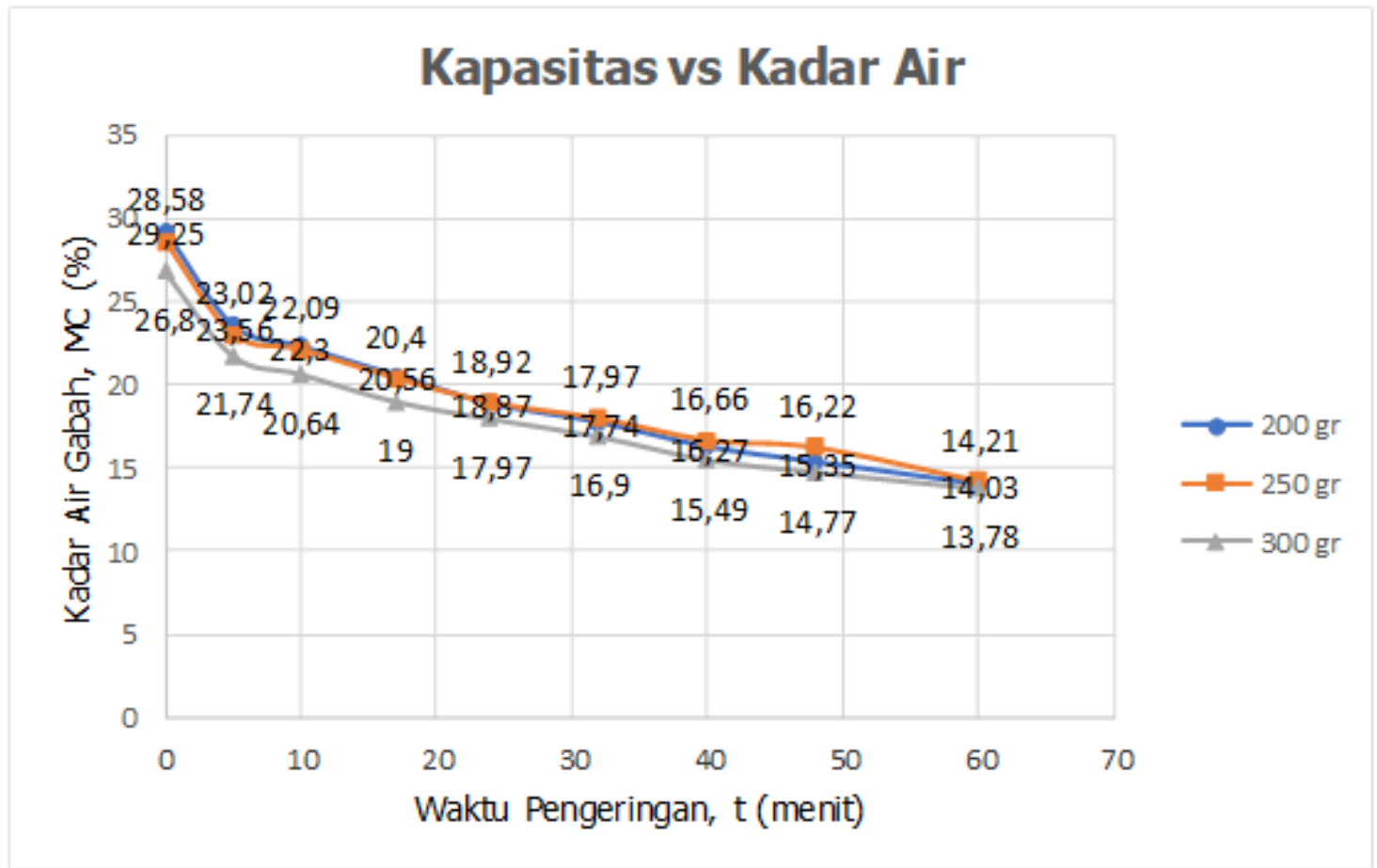

Gambar 3. Hubungan kapasitas pengeringan dengan penurunan kadar air gabah fungsi waktu pengeringan

Penurunan persentase kadar air gabah terjadi secara signifikan pada 5 menit pertama pengeringan yakni $5.69 \%$ sama dengan $14.89 \mathrm{gr}$ air yang diuapkan, 5.56\% sama dengan $18.06 \mathrm{gr}$ air yang diuapkan dan $5.06 \%$ sama dengan $19.40 \mathrm{gr}$ air yang diuapkan dan persentase ini juga menunjukkan bahwa gabah dengan kadar air awal besar memiliki persentase laju penurunan kadar air terbesar di 5 menit pertama namun massa penguapan uap air terbesar terjadi pada kapasitas pengeringan $300 \mathrm{gr}$ karena memiliki massa air yang tertinggi sebelum gabah dikeringkan yakni sebesar $80.4 \mathrm{gr}$. Dari semua kapasitas pengeringan rata-rata penurunan kadar air gabah lebih dari $50 \%$.

Secara umum bahan akan mengalami penurunan kadar air selama proses pengeringan. Gambar 4 menunjukkan bahwa pada awal proses pengeringan jumlah uap air yang diuapkan lebih banyak dibandingkan dengan menit-menit berikutnya, hal ini disebabkan perbedaan konsentrasi massa air pada bagian dalam dan permukaan gabah. Konsentrasi massa air dipermukaan gabah lebih rendah dibandingkan dengan konsentrasi massa air di dalam gabah, hal ini disebabkan karena air yang berada di bagian permukaan gabah lebih cepat menjadi uap karena adanya kontak langsung dengan udara panas pengering (Amin et al.,2018). Penguapan air pada awal pengeringan yang lebih besar juga disebabkan karena meningkatnya temperatur udara pengering sehingga kemampuan bahan untuk melepaskan air dari permukaannya akan semakin besar. Makin tinggi suhu udara pengering makin besar energi panas yang dibawa udara sehingga makin banyak jumlah massa cairan yang diuapkan dari permukaan bahan yang dikeringkan (Taufiq,2004). Sedangkan pada menit selanjutnya temperatur udara pengering cenderung lebih stabil. Temperatur gabah meningkat seiring dengan berpindahnya panas dari udara pengering ke gabah sehingga selisih antara temperatur udara dengan gabah semakin kecil yang menyebabkan massa uap air yang diuapkan menjadi lebih sedikit dikarenakan perpindahan panas yang terjadi semakin kecil (Permana, 2016).

Air yang diuapkan dengan jumlah yang lebih banyak pada awal pengeringan adalah kadar air bebas dipermukaan bahan dengan laju pengeringan konstan kemudian diikuti dengan laju pengeringan menurun. Kedua periode ini dibatasi oleh kadar air kritis yakni kadar air 
terendah dimana laju air bebas dari dalam bahan ke permukaan tidak terjadi lagi (Prabowo, 2009).

Gambar 4 juga menunjukkan bahwa kapasitas pangeringan yang lebih besar memiliki massa air yang diuapkan yang lebih besar terutama terlihat pada menit awal pengeringan yakni sebesar $19.40 \mathrm{gr}$ dengan kapasitas $300 \mathrm{gr}$, sedangkan kapasitas $250 \mathrm{gr}$ dan $200 \mathrm{gr}$ mengeluarkan uap air masing-masing sebesar $18.06 \mathrm{gr}$ dan $14.89 \mathrm{gr}$. Secara keseluruhan kapasitas pengeringan yang paling besar juga mengeluarkan uap air dengan jumlah yang paling besar yakni sebesar $41.82 \mathrm{gr}$.

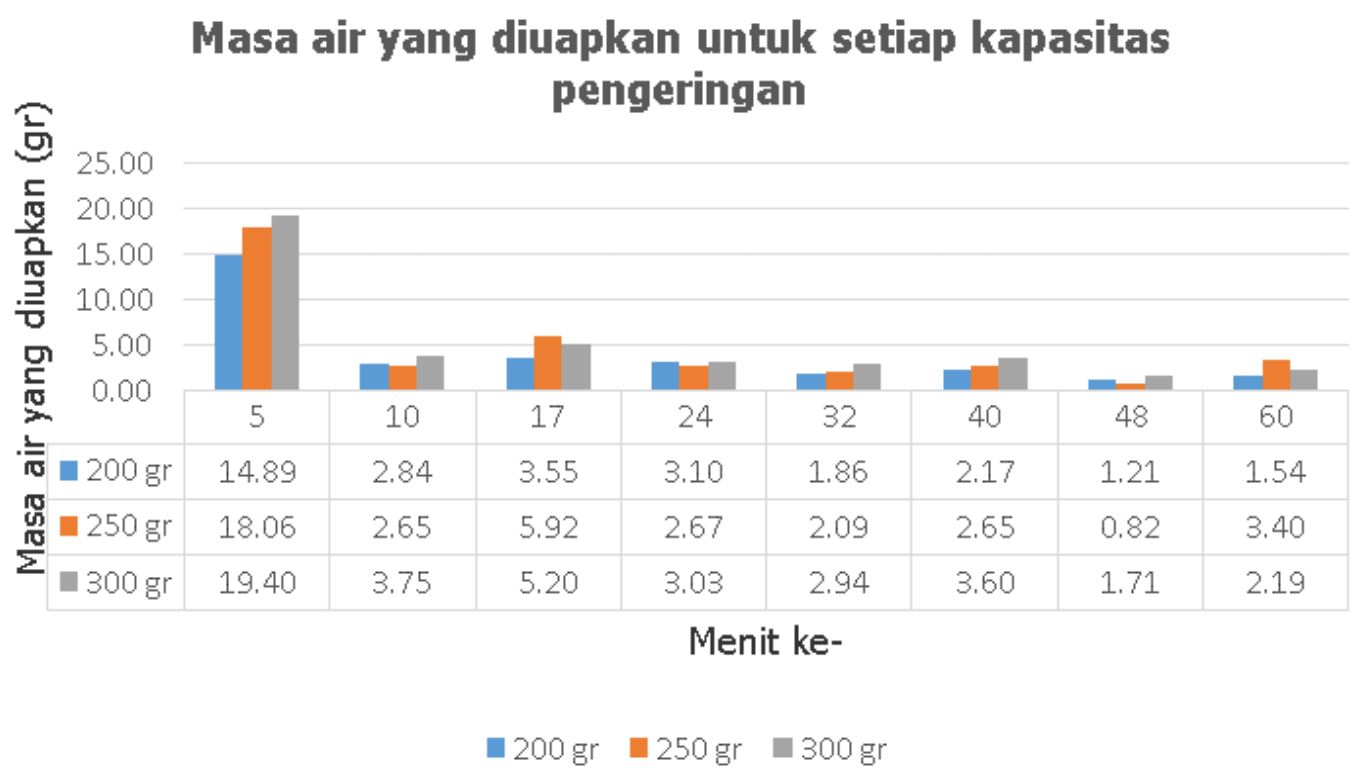

Gambar 4. Jumlah massa air yang diuapkan pada setiap pengambilan sampel untuk kapasitas $200 \mathrm{gr}, 250 \mathrm{gr}$ dan $300 \mathrm{gr}$

Humidity ratio menunjukkan jumlah massa kadar air yang terdapat dalam $1000 \mathrm{gr}$ udara kering. Gambar 5, 6 dan 7 menunjukkan jumlah air dalam udara kering di setiap kapasitas pengeringan pada plenum dan ruang pengering. Pada menit ke-0 pengeringan sebelum udara panas dihembuskan ke ruang pengering yang melewati plenum, humadity ratio pada plenum dan ruang pengering relatif sama untuk semua kapasitas pengeringan dikarenakan temperatur yang masih rendah dan kelembaban relatif yang masih tinggi serta udara pengering belum dialirkan. Setelah lima menit pengeringan humidity ratio pada plenum dan ruang pengering berbanding terbalik, humidity ratio pada ruang pengering mulai naik dimana temperatur udara dinaikkan dan udara dialirkan melewati plenum dan menerbangkan gabah pada ruang pengeringan. Hal ini menunjukkan bahwa sudah ada air yang dilepaskan bahan yang dibawa oleh udara panas pengeringan. Sedangkan pada menit yang sama humidity ratio pada plenum turun seiring dengan naiknya temperatur. Selisih humidity ratio $(\Delta \mathrm{w})$ antara ruang pengering dengan plenum menunjukkan jumlah air dalam $1000 \mathrm{~g}$ udara kering yang diperoleh dari gabah yang dikeringkan. Rata-rata Selisih humidity ratio $(\Delta \mathrm{w})$ antara ruang pengering dengan plenum pada menit akhir pengeringan untuk semua variasi kapasitas sebesar $5-7 \mathrm{~g} / \mathrm{kg}$. 


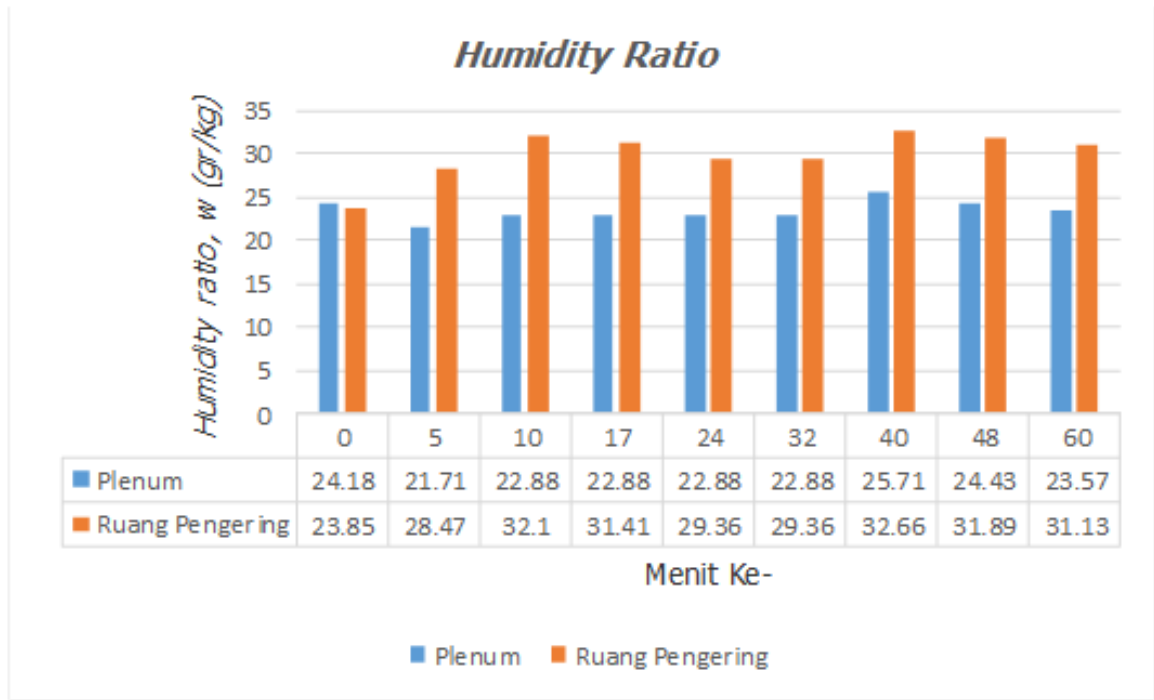

Gambar 5. Humidity ratio plenum dengan ruang pengering kapasitas pengeringan $200 \mathrm{gr}$

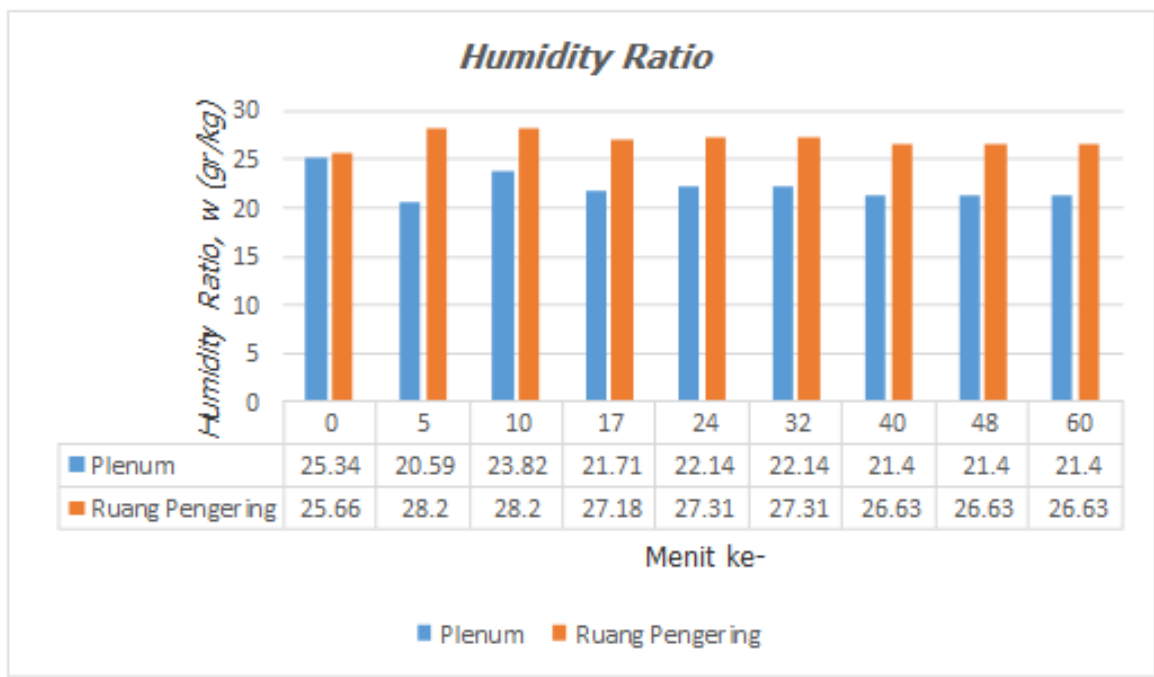

Gambar 6. Humidity ratio plenum dengan ruang pengering kapasitas pengeringan $250 \mathrm{gr}$

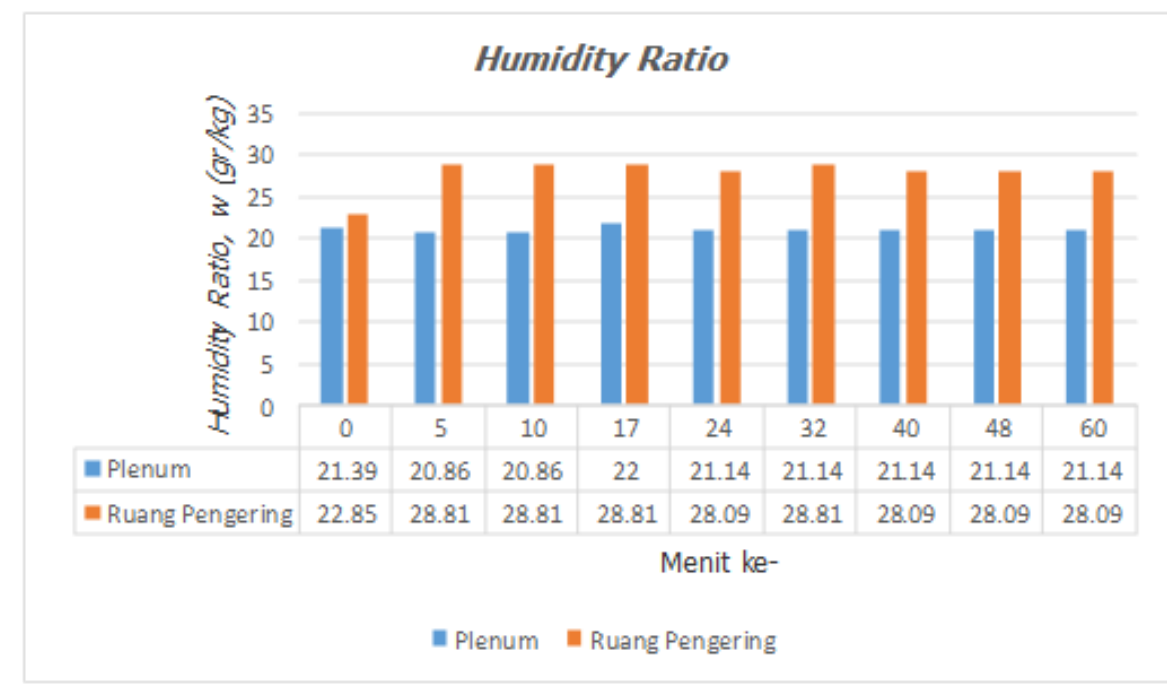

Gambar 7. Humidity ratio plenum dengan ruang pengering kapasitas pengeringan $300 \mathrm{gr}$ 
Pada proses pengujian pengeringan gabah menggunakan swirling fluidized bed dryer, massa gabah terus berkurang sebagai akibat dari air yang diuapkan dan dari pengurangan gabah yang diambil sebagai sampel untuk diukur kadar airnya. Gambar 8, 9 dan 10 menunjukkan penurunan kadar air gabah pada setiap menit pengambilan sampel dilihat dari massa gabah yang tersisa dari pengambilan sampel sebelumnya. Trendline penurunan kadar air gabah menunjukkan kesamaan pada setiap kapasitas pengeringan. Laju penurunan kadar air gabah berbanding lurus dengan penurunan massa gabah yang tersisa pada menit selanjutnya. Massa total gabah (massa padatan dan massa air) yang berkurang pada setiap kapasitas pengeringan dari awal hingga akhir pengeringan lebih kurang sebesar $50 \%$.

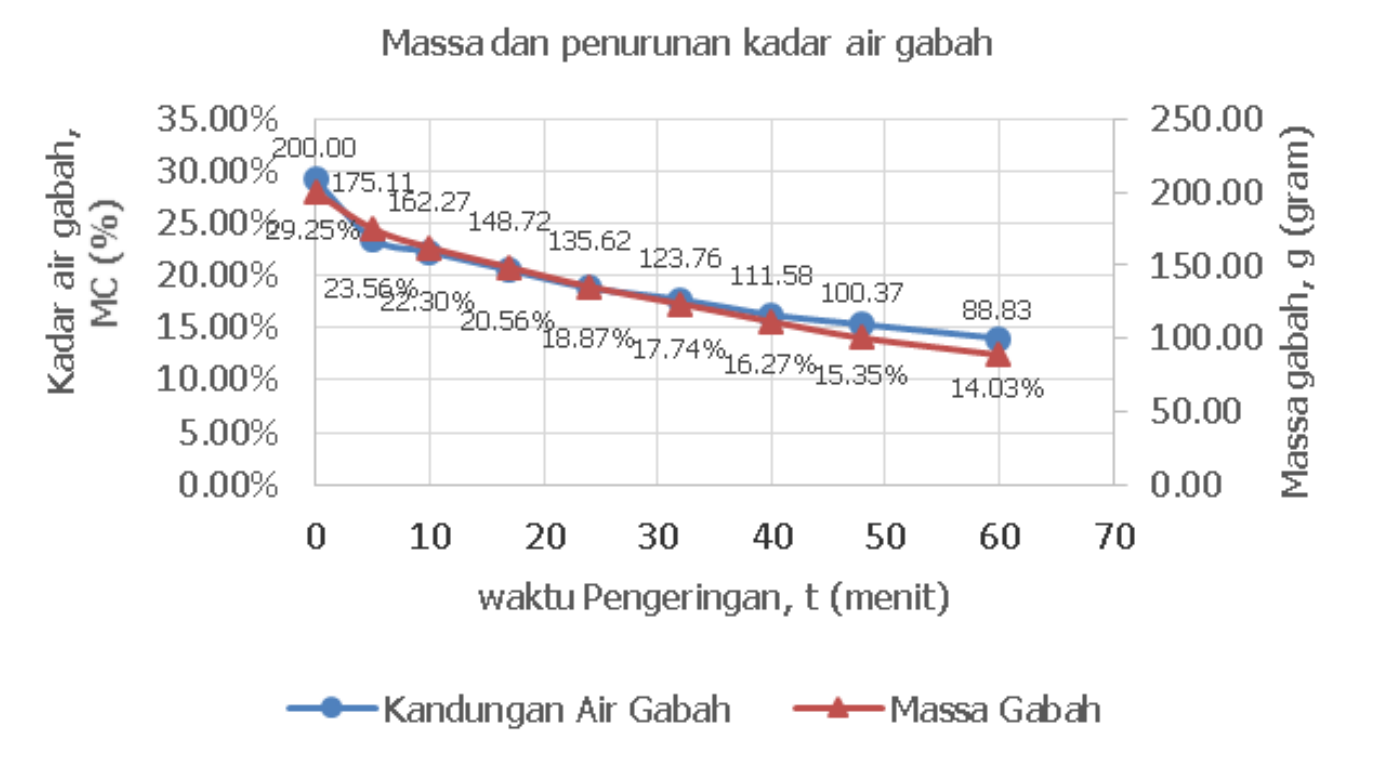

Gambar 8. Penurunan kadar air gabah dan massa gabah yang dikeringkan (Kapasitas awal pengeringan $200 \mathrm{gr}$ )

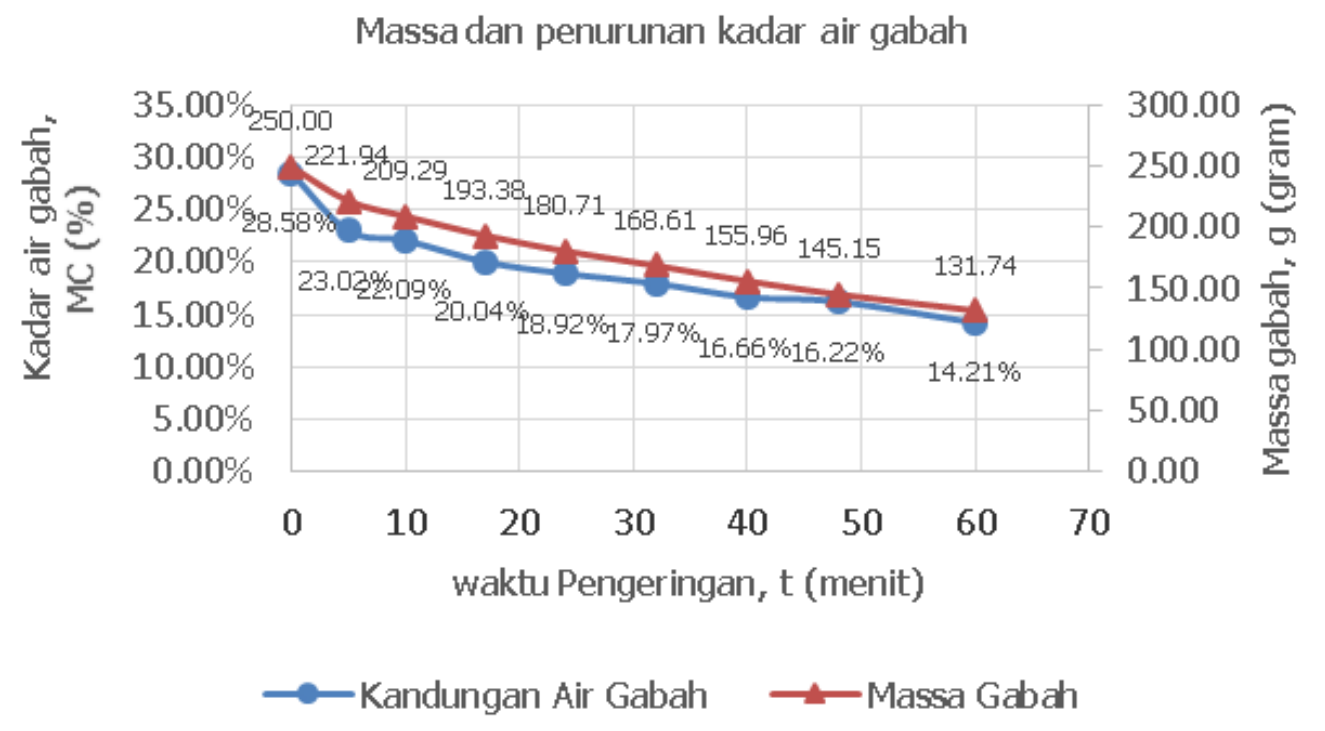

Gambar 9. Penurunan kadar air gabah dan massa gabah yang dikeringkan (Kapasitas awal pengeringan $250 \mathrm{gr}$ ) 
Temperatur udara pengering sangat mempengaruhi kelembaban udara di dalam ruang pengering dan laju penurunan kadar air bahan yang akan dikeringkan. Menaikkan temperatur udara pengering dimaksudkan untuk memperkecil kandungan uap air pada udara yang mengalir sehingga udara mampu menampung lebih banyak uap air dari bahan yang mengakibatkan laju pengeringan akan lebih cepat. Perbedaan temperatur udara pengering dengan temperatur bahan yang besar akan mempercepat proses pindah panas dari udara pengering ke dalam bahan sehingga penguapan air dari dalam bahan ke udara akan semakin banyak dan semakin cepat. Kelembaban udara mempengaruhi tekanan uap air pada bahan, kelembaban udara tinggi mengakibatkan perbedaan tekanan uap air di dalam dan di luar bahan menjadi kecil sehingga menghambat perpindahan uap air dari dalam bahan ke luar (Stefanus dan Kosasih, 2014).

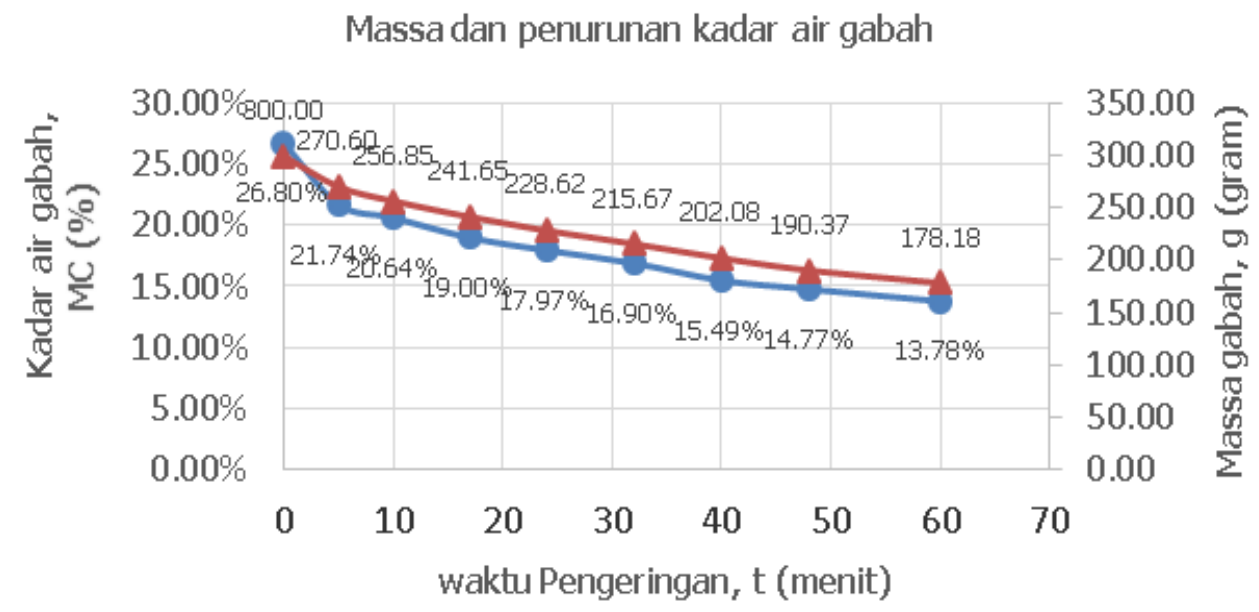

$\longrightarrow$-Kandungan Air Gabah $\quad$ —Massa Gabah

Gambar 10. Penurunan kadar air gabah dan massa gabah yang dikeringkan (Kapasitas awal pengeringan $300 \mathrm{gr}$ )

Pada gambar 11, 12 dan gambar 13 menunjukkan pengaruh dari kenaikan temperatur udara pengering terhadap perubahan kelembaban relatif (kadar air yang ada dalam udara) untuk masing-masing kapasitas pengeringan 200 gr, $250 \mathrm{gr}$ dan $300 \mathrm{gr}$. Trendline grafik menunjukkan karakteristik yang sama untuk semua variabel kapasitas pengeringan. Kenaikan temperatur ruang pengering pada lima menit pertama pengeringan sangat signifikan yakni dari temperatur ruang antara $32^{\circ} \mathrm{C}$ hingga $33^{\circ} \mathrm{C}$ menjadi $45^{\circ} \mathrm{C}$ hingga $47{ }^{\circ} \mathrm{C}$. Pengaruh dari kenaikan temperatur ini menurunkan kadar air dalam udara pada ruang pengering sehingga penurunan kadar air (moisture content) dari dalam gabah ke udara juga signifikan sebagaimana yang ditunjukkan pada gambar 2 . Temperatur dari menit ke-10 hingga menit akhir (menit ke-60) pengeringan tidak berubahan secara signifikan sehingga penurunan kadar air dalam udara kering atau perubahan kelembaban relatif cenderung stabil dan bahkan tidak mengalami perubahan. Selain temperatur, kecepatan aliran udara juga sangat mempengaruhi kecepatan proses pengeringan. Kecepatan aliran udara pengering makin tinggi maka makin cepat pula massa uap air yang dipindahkan dari bahan ke atmosfir (Stefanus dan Kosasih, 2014). Pada penelitian ini kecepatan rata-rata aliran udara di atas annular blade distributor sebesar $9.38 \mathrm{~m} / \mathrm{s}$ pada setiap kapasitas pengujian. 


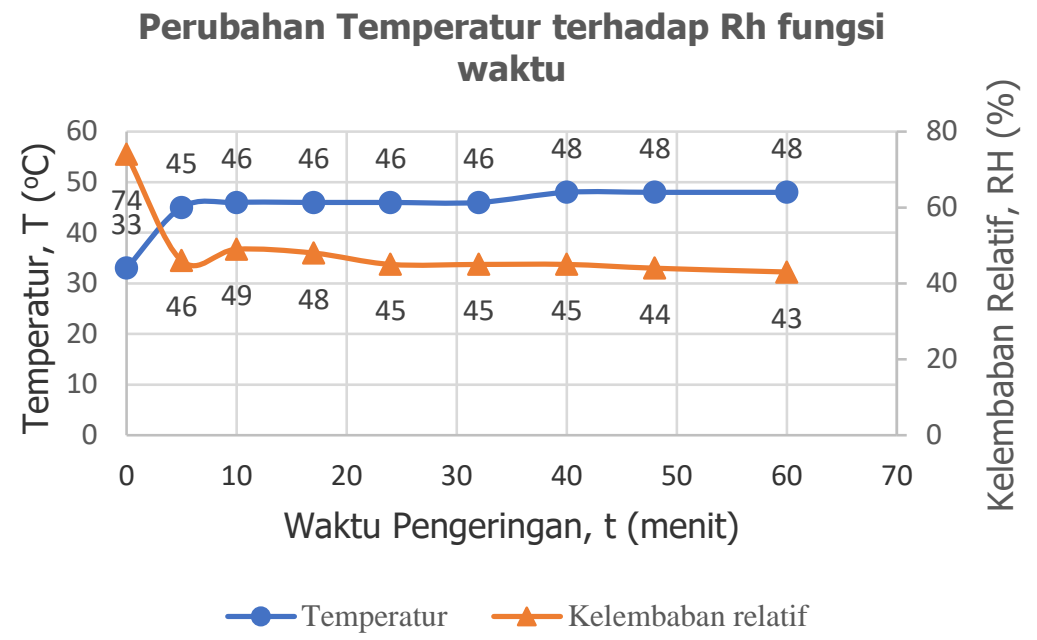

Gambar 11. Pengaruh perubahan temperatur terhadap kelembaban relatif pada ruang pengering kapasitas $200 \mathrm{gr}$

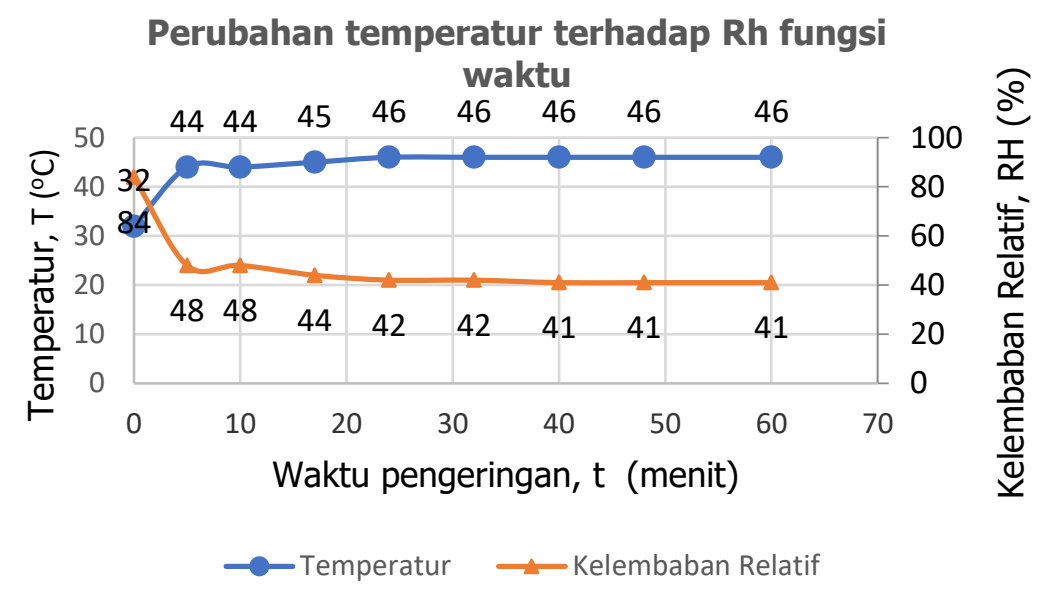

Gambar 12. Pengaruh perubahan temperatur terhadap kelembaban relatif pada ruang pengering kapasitas $250 \mathrm{gr}$

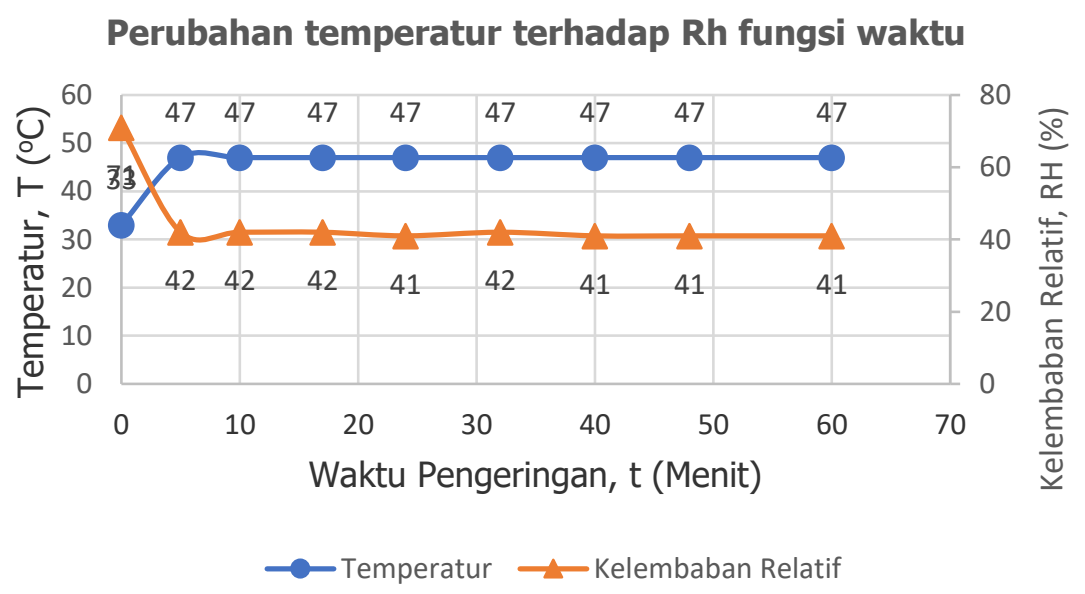

Gambar 13. Pengaruh perubahan temperatur terhadap kelembaban relatif pada ruang pengering kapasitas $300 \mathrm{gr}$ 


\section{KESIMPULAN}

Pengeringan gabah menggunakan alat pengering SFBD untuk kapasitas $200 \mathrm{gr}$, $250 \mathrm{gr}$ dan $300 \mathrm{gr}$ memiliki tren laju penurunan kadar air yang seragam dari awal hingga 60 menit pengeringan. Pengeringan dengan kapasitas terbesar yakni sebesar $300 \mathrm{gr}$ mampu mengurangi kadar air gabah hingga $13.78 \%$ dengan jumlah massa air yang diuapkan sebesar $41.82 \mathrm{gr}$ pada akhir pengeringan. Penurunan persentase kadar air gabah terjadi secara signifikan pada 5 menit awal pengeringan rata-rata sebesar $5 \%$ untuk setiap kapasitas pengeringan dan rata-rata $1 \%$ pada menit berikutnya hingga akhir pengujian.

Mulai terjadi penurunan Humidty ratio plenum pada 5 menit pengeringan kemudian naik pada menit berikutnya hingga menit akhir pengeringan namun tidak melebihi humidty ratio pada menit ke-0. Humidty ratio ruang pengering berbanding terbalik dengan plenum, pada menit ke-5 pengeringan humidty ratio ruang pengering naik, hal ini menunjukkan ada uap air dari gabah yang dibawa udara pengering.

Perubahan temperatur sangat mempengeruhi kelembaban relatif ruang pengering yang kemudian akan mempengaruhi kecepatan pengeringan bahan. Kenaikan temperatur yang signifikan pada menit ke-5 pengeringan menyebabkan kelembaban relatif ruang pengering turun karena air dalam udara pada ruang pengering dilepas ke lingkungan sehingga udara pada ruang pengering mampu menampung uap air dari gabah. Kenaikan temperatur rata-rata $13-14^{\circ} \mathrm{C}$ dan menurunkan kelembaban udara $28-36 \%$.

\section{UCAPAN TERIMA KASIH}

Pada kesempatan ini penulis mengucapkan terima kasih kepada Kepala P2 TTG-LIPI, yang telah menfasilitasi penelitian ini, rekan-rekan peneliti dan litkayasa di Pusat Penelitian Teknologi Tepat Guna, Lembaga Ilmu Pengetahuan Indonesia, dan semua pihak yang tidak dapat disebutkan satu persatu yang membantu dalam penelitian ini dalam bentuk apapun.

\section{DAFTAR PUSTAKA}

Amin, A. Jamaluddin dan Rais, M. 2018. Laju Pindah Panas Dan Massa Pada Proses Pengeringan Gabah Menggunakan Alat Pengering Tipe Bak (Batch Dryer). Jurnal Pendidikan Teknologi Pertanian 4( ): S87-S104.

Batcha, M.F.M., Sulaiman,S.A., dan Raghavan, V.R. Hydrodinamic of Oil Palm Fron in a Swirling Fluidized Bed Dryer. Applied Mechanic and Materials. 117-119( ): 1829-1833.

Dina, S.F., Limbong, H.P., dan Rambe. S. M. 2018. Rancangan Dan Uji Performansi Alat Pengering Tenaga Surya Menggunakan Pompa Kalor (Hibrida) Untuk Pengeringan Biji Kakao. Jurnal Riset Teknologi Industri 12(1): 21-33

Data Produksi Padi dan Luas Area Panen Nasional periode 2011-2015. https://www.bps.go.id/subject/53/tanaman-pangan.html\#subjekViewTab3.

Dwika, R.T., Ceningsih, T. dan Sasongko, S.B. 2012. Pengaruh suhu da laju alir udara pengeringan pada pengeringan karaginan menggunakan teknologi Spray dryer. Jurnal Teknologi Kimia dan Industri 1(1): 298-304.

Ferdiansyah, H. 2003. Kinerja Sistem Pengering Tipe Efek Rumah Kaca Dengan Mekanisme Penggetaran. Skripsi. Iinstitut Pertanian Bogor (IPB). Bogor.

Kunii, D., dan Levenspiel, O. 1991. Fluidization Engineering. Second edition. ButterworthHeinemann. United State of America.

Lee, C.H. dan Chungt, D.S. 1985. Physical and Thermal Properties of Grains. Proceedings of an international seminar held at Kuala Lumpur, Malaysia. October 9-11.

Napitu, Y.O. 2016. Desain Model Pengering Spouted Bed Dua Dimensi Untuk Pengeringan Gabah. Thesis. Iinstitut Pertanian Bogor (IPB). Bogor. 
Oktianto, A.T. dan Prabowo. 2014. Studi Eksperimen Pengaruh Sudut Blade Tipe Single Row Distributor pada Swirling Fluidized Bed Coal Dryer terhadap Karakteristik Pengeringan Batu bara. Jurnal Teknik POMITS 3(1): B86-B90.

Permana, D. dan Prabowo. 2016. Studi Eksperimen Pengaruh Kecepatan Udara Pengering Inlet Chamber pada Swirling Fluidized Bed Dryer Terhadap Karakteristik Pengeringan Batubara. JURNAL TEKNIK ITS 5(2): B684-B689.

Prabowo, R.A. 2009. Penentuan model kadar air keseimbangan dan konstanta pengeringan kapulaga (amomum cardamomum willd) dengan metode dinamis. Skripsi. Institut Pertanian Bogor (IPB). Bogor.

Rahayuningtyas, A. dan Kuala, S.I. 2016. Pengaruh Suhu Dan Kelembaban Udara Pada Proses Pengeringan Singkong (Studi Kasus: Pengering Tipe Rak). Jurnal Penelitian Dan Pengabdian Masyarakat 4(1): 99-104.

Stefanus, M. dan Kosasih, E. A. 2014. Pengaruh kelembaban, laju aliran dan temperatur udara pengering terhadapa laju pengeringan gula aren. FT UI.

Syarief, R., dan H. Halid. 1993. Teknologi Penyimpanan Pangan, Arcan. Jakarta.

Taib, G., Said, G. dan Wiraatmadja, S. 1988. Operasi pengeringan pada pengoloahan hasil pertanian. Edisi Pertama. PT. Mediyatama Sarana Perkasa. Jakarta.

Taufiq, M. 2004. Pengaruh Temperatur Terhadap Laju Pengeringan Jagung Pada Pengering Konvensional Dan Fluidized Bed. Skripsi. Fakultas Teknik Universitas Sebelas Maret Surakarta. Surakarta.

Yahya, M. 2015. Kajian Karakteristik Pengering Fluidisasi Terintegrasi dengan Tungku Biomassa untuk Pengeringan Padi. Jurnal Teknik Mesin 5(2): 65-71. 